\title{
The Influence of Large Shareholders' Equity Pledge on the Corporate Risk-Taking and Performance
}

\author{
Huayan Cai \\ Department of Accounting, Management School, Jinan University, Guangzhou, China \\ Email:m13760808379@163.com
}

How to cite this paper: Cai, H.Y. (2019) The Influence of Large Shareholders' Equity Pledge on the Corporate Risk-Taking and Performance. Journal of Service Science and Management, 12, 451-463.

https://doi.org/10.4236/jssm.2019.123031

Received: March 3, 2019

Accepted: April 25, 2019

Published: April 28, 2019

Copyright $\odot 2019$ by author(s) and Scientific Research Publishing Inc. This work is licensed under the Creative Commons Attribution International License (CC BY 4.0).

http://creativecommons.org/licenses/by/4.0/

\section{(c) (i) Open Access}

\begin{abstract}
With the continuous development of the capital market, the behavior of the large shareholders in the capital market of listed companies has become more and more common, among which the shareholders' equity pledge has been widely concerned by the media, investment institutions and investors. Large shareholders' equity pledge changes their portfolio risks, and the risk of their shareholders' portfolio will affect the corporate risk-taking and performance at the same time. Therefore, it is necessary to study the mechanism of the impact of major shareholders' equity pledge on corporate risk-taking and performance, so as to expand the research perspective of the impact of major shareholders' characteristics on corporate risk-taking. In order to achieve this goal, this paper studies the impact of large shareholders' equity pledge on corporate risk-taking and corporate performance by taking the data of Shanghai and Shenzhen A-share listed companies from 2010 to 2017 as samples. The findings of this study are as follows: 1) The pledge of large shareholders' equity increases the risk-taking of enterprises, which has a negative impact on the performance of enterprises; 2) The pledge of equity for different purposes will bring different economic consequences, that is, the investment of pledged capital in enterprises can improve the risk-taking of enterprises better than that in enterprises outside, and has a more significant negative impact on enterprise performance.
\end{abstract}

\section{Keywords}

Pledge Equity, Corporate Risk-Taking, Corporate Performance

\section{Introduction}

In 1995, the Guarantee Law of the People's Republic of China was promulgated 
and implemented, which allows shareholders to obtain funds by pledging their stocks legally. The reform of non-tradable shares began in 2005 and was basically completed by the end of 2008 in China. Since then, equity pledge has gradually become a relatively popular new financing means, because it can still enable the pledgee to own the right of operating and decision-making and it is much easier than other financing means. Consequently, equity pledge is more rapid and widely favored by large shareholders of listed companies, and has become a common financing method, providing great convenience for financing of listed companies. On the other hand, large-scale equity financing will also threaten the stability of large shareholders and cause the risk of equity change, having a negative impact on corporate performance. Therefore, the impact of equity pledge on enterprises is still a question to be explored. Based on the research of scholars at home and abroad and combined with China's unique economic environment and institutional background, this paper examines the relationship between equity pledge and corporate risk-taking and performance using the data of A-share listed companies in Shanghai and Shenzhen Stock Exchanges from 2010 to 2017, and finds that equity pledge improves the level of corporate risk-taking and reduces corporate performance according to Principal-Agent Theory, Control Benefit Theory and Portfolio Theory.

This paper can provide convenience for expanding the theoretical research perspective of corporate risk-taking; it also has some enlightenment for the research of equity pledge at the same time. Obviously, this paper is different from the existing studies on the static characteristics of large shareholders, such as the nature of large shareholders. It also examines the impact of large shareholders' equity pledge behavior on corporate risk-taking from the perspective of dynamic portfolio adjustment by large shareholders. But when choosing the alternative indicators of corporate performance, only accounting indicators are used to measure corporate performance, which is not so good because different companies adopt different accounting methods, and accounting indicators are easy to be manipulated, and it is easy to make the research data lose its appropriateness.

The article is organized as follows: The first part of this paper is the "introduction". It introduces the research background and significance of the article, then elaborates theoretical or empirical contributions and the limitations, and puts forward the main innovation points and the structure which paves the way for the following discussion in detail. The second part is "literature review". This paper summarizes the relevant literature on major shareholders' equity pledge, corporate risk-taking and corporate performance, reviews and combs the previous studies on the impact of major shareholders' equity pledge on corporate risk-taking and corporate performance. The third part is "research hypothesis", through a brief overview of the theory, combines with the existing theory to explore the equity pledge and risk-taking, and further derive its impact on corporate performance, thus putting forward the hypothesis of this paper. The fourth part is "research design". Firstly, the sample source, classification and selection 
criteria used in this paper are briefly described. Variables studied are determined, including explanatory variables, interpreted variables, control variables and adjustable variables. Based on the empirical model, we use stata for statistical analysis of the data, which is the fifth part, and according to the results of the hypothesis we verify and explain the empirical results. The fifth part is "research conclusions". Through the summary and analysis of the research results, the conclusion of the article is drawn, and according to the conclusion, appropriate suggestions are put forward to standardize the pledge of large shares, to determine the mechanism of the level of risk-taking and to improve the performance of the company.

\section{Literature Review}

\subsection{The Impact of Major Shareholder Characteristics on Corporate Risk-Taking}

Existing studies have studied the impact of large shareholder nature and large shareholder portfolio dispersion on corporate risk-taking. Boubakri et al. (2013) [1] studied the impact of the nature of major shareholders on corporate risk-taking. The results show that foreign-funded holding companies and family-controlled companies are positively correlated with risk-taking, while state-owned holding companies and bank-controlled companies are negatively correlated with risk-taking. Faccio et al. (2011) [2] studied the impact of the dispersion of the large shareholders' portfolio on the risk-taking of the company. After examining the number of large shareholders holding listed companies and the related indicators of the company's risk, it was found that there was a positive correlation between the two. The low risk dispersion of the large shareholders' portfolio led the company to reject the risk items beneficial to medium and small shareholders. Existing literature studies the role of corporate governance mechanisms. In view of the fact that the low risk dispersion of large shareholders' portfolio leads to the rejection of risk items beneficial to medium and small shareholders, the mechanism of corporate governance has been studied in the existing literature. For example, John et al. (2008) [3] found that the higher degree of investor protection in 39 countries, the higher the risk-taking of large shareholder-controlled companies. Bauguess et al. (2012) [4] studied the changes of corporate risk-taking after adopting dual ownership structure. The results show that when listed companies adopt dual ownership structure, large shareholders reduce their share-holding ratio without losing control. Listed companies expand their risk-taking by increasing $\mathrm{R} \& \mathrm{D}$ investment and capital expenditure, reducing diversification and increasing financial leverage. Kusnadi (2015) [5] found that countries with insider trading restrictions have higher corporate risk-taking. Mishra (2011) [6] research shows that the existence of multiple major shareholders helps to improve corporate risk-taking. Bargeron et al. (2010) [7], Acharya et al. (2011) [8] found that accounting information disclosure rules, changes in government regulation also have an impact on corpo- 
rate risk-taking.

\subsection{The Economic Consequences of the Pledge of Shareholders' Equity Rights}

Existing research mainly examines the impact of large shareholders' equity pledge on the company from the perspectives of tunneling behavior, risk of control transfer, creditor supervision effect and market value management. Xiangchao Hao and Qi Liang (2009) [9] studied the impact of equity pledge of major shareholders on corporate value from the perspective of "tunneling behavior" of major shareholders. The results show that equity pledge will reduce the actual cash flow rights of the ultimate controller, thus weakening the incentive effect. Moreover, equity pledge will increase the separation between actual cash flow and control rights, thus strengthening the embezzlement effect, that is, after equity pledge is large. Shareholders have increased their tunneling behavior. Bin Wang et al. (2013) [10] studied the impact of the pledge of large shareholders' equity on corporate performance from the perspective of the risk of control transfer. The results show that with the increase of control risk transfer, large shareholders adopted long-term strategies such as improving corporate governance and management and improving performance. Yan Tan and Jing $\mathrm{Wu}$ (2013) [11] studied the relationship between equity pledge of major shareholders and corporate performance from the perspective of supervisory effect of creditor's rights bank. The results show that creditor's rights bank uses the "incentive effect" of pledge quality to control credit risk, which reduces the agency cost of debt, but the political relationship embodied by the nature of equity weakens the political role of equity pledge. Jun Li and Guojian Zheng (2015) [12] studied the governance effect of large shareholders' equity pledge on the behavior of interest peculation from the perspective of market value management.

\section{Hypothesis}

\subsection{The Impact of Pledge Ratio on the Corporate Risk-Taking}

Through equity pledge, the risk of large shareholders' investment portfolio can be effectively dispersed. The increase of risk dispersion makes large shareholders more inclined to invest in high-risk projects (Amihud, (1990) [13]). Therefore, the higher the equity pledge rate, the higher the degree of diversification of the shareholders' portfolio (Faccio et al., (2011) [2]; Bauguess et al., (2012) [4]). The higher the risk preference degree of the large shareholders (Yeh, (2003) [14]), the higher the risk-taking level of the company. Based on the above conclusions, we get the first hypothesis:

Hypothesis 1: The higher the proportion of equity pledge of major shareholders in listed companies, the higher the level of risk-taking.

\subsection{The Impact of Pledge Ratio on Corporate Performance}

As we know, equity pledge can also affects corporate performance through 
risk-taking. This impact may be reflected in three aspects: Firstly, the large shareholders obtain funds from equity pledge aiming at beneficial investment to promote corporate performance; secondly, excessive risk-taking will lead to deviations from the target capital structure, increase the cost of capital, and then reduce the value of enterprises (Dong et al. (2010) [15]); thirdly, the large shareholders will also pledge their equity to obtain funds for individual investment, making enterprises take risks but without benefits. So we cannot decide whether the pledge of large shareholders' equity can improve the performance of enterprises or not. Thus, the second hypothesis of this paper is obtained:

Hypothesis 2a: The higher the equity pledge ratio of the major shareholders, the higher the performance level of the company.

Hypothesis $2 \mathrm{~b}$ : The higher the equity pledge ratio of the major shareholders, the lower the performance level of the company.

\subsection{The Moderating Effect of Major Shareholders' Pledge Use on Corporate Risk-Taking and Performance}

According to Faccio et al. (2011) [2], Bauguess et al. (2012) [4] and Markowitz's portfolio theory, it can be seen that the higher the dispersion of large shareholders' portfolio, the higher the risk-taking of the company. Compared with investing in the enterprise, investing outside is more conducive to the diversification of the investment portfolio. This may further enhance the risk preference of major shareholders and the motivation of "risk transfer", lead to excessive risk-taking and deviation from the target capital structure, thereby damaging the interests of creditors and small and medium shareholders, and increasing the agency costs of enterprises (Dong et al. (2010) [15]), and reducing corporate performance. In addition, when the capital obtained by equity pledge is invested outside the enterprise, the capital and income cannot flow into the enterprise, and can't promote the production and operation of the enterprise, so the investment outside will have a more negative impact on the performance of the enterprise. We propose hypotheses 3 and 4 :

Hypothesis 3: Compared with the company whose purpose of pledged capital is to invest in the enterprise itself, the company whose purpose of pledged capital is to invest outside the enterprise has a higher positive correlation between the pledge ratio of major shareholders' equity and the risk-taking of the company.

Hypothesis 4: Compared with the company whose purpose of pledge fund is to invest in the enterprise itself, the company whose purpose of pledge fund is to invest outside the enterprise, the pledge ratio of major shareholders' equity has a higher negative correlation with the company's performance.

\section{Research Design}

\subsection{Data Sources}

This paper chooses the financial data of Shanghai and Shenzhen A-share listed 
companies from 2010 to 2017. Specifically, the equity pledge data comes from RESSET financial database, and other financial data comes from CSMAR database. In order to maintain the integrity and reliability of data, this paper excludes a few companies that lack data. At the same time, because the financing behavior of the financial insurance industry has its industrial characteristics, and its financial data has particularity, the sample companies of the industry are also excluded.

\subsection{Definition of Variables}

- Explanatory variables. In this paper, Pledge is chosen to measure the pledge behavior of the major shareholders, which refers to the proportion of the amount of large shareholders' equity pledge to the shares of the listed companies they hold.

- Interpreted variable. There are two interpreted variables in this paper. One is corporate risk-taking, referring to the method of Minggui Yu (2013) [16], we use the volatility of ROA to measure the corporate risk taking in the main regression. The other is enterprise performance, which is measured by ROA and EBIT.

- Moderating Variable. The purpose of obtaining funds by pledge is taken as a moderating variable.

- Control variables. The main variables about company's basic information are shown in Table 1.

Table 1. The measurement of main variables.

\begin{tabular}{|c|c|c|c|}
\hline Category & Variable Meaning & Label & Definition \\
\hline & Risk-taking & Rt_roa & Industry-adjusted Roa Volatility \\
\hline $\begin{array}{l}\text { Interpreted } \\
\text { variable }\end{array}$ & $\begin{array}{l}\text { Return on Total } \\
\text { Assets }\end{array}$ & Roa & $\begin{array}{l}\text { Next Period Net Profit/Next } \\
\text { Period Total Assets }\end{array}$ \\
\hline $\begin{array}{l}\text { Explanatory } \\
\text { variables }\end{array}$ & Pledge ratio & Pledge & $\begin{array}{c}\text { Number of large shareholders' Pledged } \\
\text { Shares/number of shares held by large } \\
\text { shareholders }\end{array}$ \\
\hline $\begin{array}{l}\text { Moderating } \\
\text { variable }\end{array}$ & Pledge use & Use & $\begin{array}{l}\text { If capital is invested outside the enterprise, } \\
\text { assign value to } 1 \text {, otherwise } 0\end{array}$ \\
\hline \multirow{7}{*}{$\begin{array}{l}\text { Controlling } \\
\text { svariables }\end{array}$} & Company size & Size & Natural logarithm of total assets \\
\hline & Asset-Liability Ratio & Lev & Ratio of Liabilities to Total Assets \\
\hline & income Growth & Growth & $\begin{array}{c}\text { (Current Operating Revenue - Last } \\
\text { Operating Revenue)/Last Operating } \\
\text { Revenue }\end{array}$ \\
\hline & $\begin{array}{l}\text { The nature of } \\
\text { property rights }\end{array}$ & Soe & State-owned enterprises 1 , the other 0 \\
\hline & Listing age & Age & $\operatorname{Ln}(1+$ year of listing $)$ \\
\hline & R \& D Inputs & $\mathrm{R} \& \mathrm{D}$ & R \& D Inputs/Total Assets \\
\hline & $\begin{array}{l}\text { Large shareholder } \\
\text { ownership holding }\end{array}$ & Hold & Large shareholder ownership ratio \\
\hline
\end{tabular}




\subsection{Model Construction}

In order to verify hypothesis 1 and 3 , we set up the following models to test them.

$$
\mathrm{Rt}_{\text {roa }}=\alpha_{0}+\alpha_{1} \text { Pledge }+\sum \text { Control }+\sum \text { Ind }+\sum \text { Year }+\varepsilon
$$

If it is significantly positive, it shows that equity pledge increases the corporate risk-taking. Hypothesis 1 of this paper has been verified.

$$
\text { Roa }=\beta_{0}+\beta_{1} \text { Pledge }+\sum \text { Control }+\sum \text { Ind }+\sum \text { Year }+\varepsilon
$$

If it is significantly negative, it shows that equity pledge reduces corporate performance. The hypothesis $2 \mathrm{~b}$ of this paper is verified. We also test the above two models in groups according to the situation of capital investment. If the corporate risk-taking and performance are higher and worse in the group of capital investment to the outside, then hypothesis 3 is tested. If the contrary situation happens, then hypothesis 4 is tested.

\section{Empirical Results}

\subsection{Descriptive Statistics}

Table 2 is the descriptive statistics of the dependent variable pledge ratio. We can see that with the passage of years, more and more enterprises participate in the equity pledge behaviors. Equity pledge has become a more common phenomenon, which is worth exploring in depth. On the other hand, the rate of equity pledge is getting lower and lower. Whether in terms of mean, lower quartile, median or upper quartile, the rate of equity pledge decreases year by year. This may be caused by two reasons. One is that shareholders and managers are aware of the risk of equity pledge, thus reducing the rate of equity pledge. Secondly, more major shareholders may participate in the pledge of equity. Compared with the small and medium shareholders, the majority shareholders hold more shares. Only a small part of the pledge can obtain the funds needed for the operation of the enterprise, so the pledge ratio is lower and the risk is more controllable.

Table 2. Descriptive statistics of equity pledge ratio.

\begin{tabular}{cccccccc}
\hline Year & $\mathrm{N}$ & Mean & Max & Min & $\mathrm{p} 50$ & $\mathrm{p} 25$ & $\mathrm{p} 75$ \\
\hline 2009 & 780 & 0.35 & 1.00 & 0.00 & 0.25 & 0.12 & 0.50 \\
2010 & 837 & 0.31 & 1.00 & 0.00 & 0.21 & 0.09 & 0.45 \\
2011 & 1366 & 0.28 & 1.00 & 0.00 & 0.18 & 0.08 & 0.38 \\
2012 & 2081 & 0.28 & 1.00 & 0.00 & 0.18 & 0.08 & 0.37 \\
2013 & 2066 & 0.29 & 1.00 & 0.00 & 0.19 & 0.08 & 0.40 \\
2014 & 2346 & 0.24 & 1.00 & 0.00 & 0.14 & 0.06 & 0.30 \\
2015 & 3646 & 0.19 & 1.00 & 0.00 & 0.11 & 0.05 & 0.24 \\
2016 & 6459 & 0.18 & 1.00 & 0.00 & 0.10 & 0.04 & 0.22 \\
2017 & 5871 & 0.16 & 1.00 & 0.00 & 0.07 & 0.02 & 0.19 \\
Total & 25,452 & 0.21 & 1.00 & 0.00 & 0.12 & 0.05 & 0.27 \\
\hline
\end{tabular}


Table 3 shows the descriptive statistical results of the dependent and control variables in this paper. There are two kinds of interpreted variables in this paper. The first type includes two ways to measure enterprise performance: return on total assets (Roa) and return on equity (Roe). The second category includes enterprise performance volatility calculated by Roa, Roe, namely risk-taking. Finally, we also make descriptive statistics on relevant control variables, including size, Lev, growth of main business, Soe, Age, R \& D investment, Hold and so on.

\subsection{Multiple Regression Analysis}

Firstly, this paper examines the relationship between equity pledge and enterprise risk-taking. As shown in Table 4, the results are divided into three columns. The first column makes a regression analysis on the equity pledge ratio and risk-taking level of large shareholders. The second and third columns are the relationship between the equity pledge ratio and the risk-taking level of the company after grouping according to the investment direction of the enterprise capital. From the regression results of the first column, the equity pledge ratio of the major shareholders is positively correlated with the corporate risk-taking. The correlation coefficient is 0.018 , and it is significant at the level of $1 \%$, which is consistent with hypothesis 1 of this paper. This shows that the higher the equity pledge ratio of major shareholders, the higher the risk-taking level of enterprises; What's more, we find that when enterprises invest capital outward, the correlation between equity pledge ratio and risk-taking is stronger. The correlation coefficient rises from 0.018 to 0.051 , and the significance is still $1 \%$. This shows that the capital invested outward significantly increases the risk-taking of enterprises. On the other hand, when enterprises invest capital in internal production and operation, it is used to expand business, turnover and so on. At the same time, the enterprise's risk-taking level is significantly reduced, and the regression coefficient from 0.018 to 0.009 . In addition, we test the regression coefficients of the two groups by t-test. The actual Chi value of the two groups is 14.4 , and it is significant at the level of $1 \%$. This shows that there is a significant difference between the internal and external investment of funds in enterprises.

Table 3. Descriptive statistics of dependent and control variables.

\begin{tabular}{cccccccc}
\hline Variable & $\mathrm{N}$ & Mean & Max & Min & p50 & p25 & p75 \\
\hline Roa & 25,452 & 0.04 & 0.19 & -0.31 & 0.04 & 0.02 & 0.06 \\
Rt_roa & 25,168 & 0.03 & 0.36 & 0.00 & 0.02 & 0.01 & 0.03 \\
Size & 25,452 & 22.13 & 25.696 & 19.090 & 22.025 & 21.345 & 22.841 \\
Lev & 25,452 & 0.438 & 0.997 & 0.049 & 0.437 & 0.272 & 0.591 \\
Growth & 24,452 & 0.333 & 4.297 & -0.701 & 0.179 & 0.020 & 0.411 \\
Soe & 25,452 & 0.937 & 5 & 0 & 1 & 1 & 1 \\
Age & 25,452 & 2.012 & 3.332 & 0 & 1.946 & 1.609 & 2.639 \\
R \& D & 25,452 & 0.007 & 0.470 & 0 & 0 & 0 & 0.001 \\
Hold & 25,452 & 32.855 & 75 & 9.080 & 31.11 & 21.59 & 41.78 \\
\hline
\end{tabular}


Table 4. The impact of corporate equity pledge on risk-taking.

\begin{tabular}{|c|c|c|c|}
\hline Rt-roa & All & Use $=1$ & Use $=0$ \\
\hline \multirow{3}{*}{ Pledge } & $0.018^{\star * *}$ & $0.051^{* * *}$ & -0.009 \\
\hline & (2.73) & $(5.42)$ & $(-1.00)$ \\
\hline & & \multicolumn{2}{|c|}{$\begin{aligned} \mathrm{Chi} & =14.4^{* * *} \\
\mathrm{P} & =0.000\end{aligned}$} \\
\hline \multirow[t]{2}{*}{ Size } & $-0.300^{* * *}$ & $-0.341^{* * *}$ & $-0.263^{* * *}$ \\
\hline & $(-36.18)$ & $(-28.03)$ & $(-23.06)$ \\
\hline \multirow[t]{2}{*}{ Lev } & $0.108^{* * *}$ & $0.170^{\star * *}$ & $0.060^{\star * *}$ \\
\hline & (13.83) & (14.16) & $(5.82)$ \\
\hline \multirow[t]{2}{*}{ Growth } & $0.024^{* * *}$ & $0.031^{\star * *}$ & $0.018^{\star * *}$ \\
\hline & $(4.86)$ & $(4.08)$ & $(2.72)$ \\
\hline \multirow[t]{2}{*}{ Soe } & 0.003 & -0.015 & $0.017^{* *}$ \\
\hline & $(0.43)$ & $(-1.63)$ & $(2.02)$ \\
\hline \multirow[t]{2}{*}{ Age } & $0.206^{* * *}$ & $0.225^{\star * *}$ & $0.177^{\star * *}$ \\
\hline & $(28.12)$ & (21.48) & $(17.03)$ \\
\hline \multirow[t]{2}{*}{$\mathrm{R} \& \mathrm{D}$} & $0.039^{* * *}$ & $0.039^{* * *}$ & $0.043^{* * *}$ \\
\hline & $(6.29)$ & $(4.16)$ & (5.11) \\
\hline \multirow[t]{2}{*}{ Hold } & -0.010 & -0.007 & -0.013 \\
\hline & $(-1.50)$ & $(-0.71)$ & $(-1.45)$ \\
\hline \multirow[t]{2}{*}{ Constant } & $0.133^{\star *}$ & $0.238^{\star * *}$ & 0.026 \\
\hline & (2.41) & $(2.86)$ & $(0.35)$ \\
\hline Indurstry & Yes & Yes & Yes \\
\hline Year & Yes & Yes & Yes \\
\hline Observations & 25168 & 11440 & 13728 \\
\hline Adjusted-R2 & 0.09 & 0.13 & 0.08 \\
\hline
\end{tabular}

Standard errors in parentheses ${ }^{* *} \mathrm{p}<0.01,{ }^{* *} \mathrm{p}<0.05,{ }^{*} \mathrm{p}<0.1$.

Generally speaking, the above regression results show that when the funds raised by equity pledge are used for different purposes, there will be different economic consequences. When the funds raised are used for investment out of the corporate, the positive correlation between the pledge ratio and the level of enterprise risk-taking is more significant than that of inner investment. Therefore, hypothesis 1 and 3 are verified.

We also examine the relationship between equity pledge and corporate performance, as is shown in Table 5. From the regression results of the whole sample, the relationship between equity pledge and corporate performance is significantly negative, the regression coefficient is -0.042 , and significant at the $1 \%$ level, indicating that equity pledge significantly reduces corporate performance, which is consistent with the assumption $2 \mathrm{~b}$ in this paper. From the perspective of control variables, the bigger the company size, the higher the income growth rate, and the larger the proportion of large shareholders, the better the performance of the company, which is the same as our expectations. In addition, the 
Table 5. The impact of equity pledge on corporate performance.

\begin{tabular}{|c|c|c|c|}
\hline Roa & All & Use $=1$ & Use $=0$ \\
\hline \multirow{4}{*}{ Pledge } & $-0.042^{\star * *}$ & $-0.060^{\star * *}$ & -0.017 \\
\hline & $(-5.84)$ & $(-6.33)$ & $(-1.60)$ \\
\hline & \multicolumn{3}{|c|}{ Chi $=7.75^{\star \star *}$} \\
\hline & & \multicolumn{2}{|c|}{$\mathrm{P}=0.005$} \\
\hline \multirow[t]{2}{*}{ Size } & $0.108^{\star \star \star}$ & $0.077^{\star \star \star}$ & $0.148^{\star \star \star}$ \\
\hline & (11.56) & $(6.16)$ & $(10.43)$ \\
\hline \multirow[t]{2}{*}{ Lev } & $-0.318^{\star * *}$ & $-0.296^{\star * *}$ & $-0.327^{\star * *}$ \\
\hline & $(-36.40)$ & $(-24.10)$ & $(-26.20)$ \\
\hline \multirow[t]{2}{*}{ Growth } & $0.089^{* * *}$ & $0.076^{* * *}$ & $0.096^{* * *}$ \\
\hline & $(16.19)$ & $(9.92)$ & $(12.25)$ \\
\hline \multirow[t]{2}{*}{ Soe } & $-0.014^{\star *}$ & 0.011 & $-0.037^{* * *}$ \\
\hline & $(-2.23)$ & $(1.22)$ & $(-4.12)$ \\
\hline \multirow[t]{2}{*}{ Age } & $-0.071^{\star * \star}$ & $-0.070^{\star * \star}$ & $-0.065^{\star * *}$ \\
\hline & $(-8.92)$ & $(-6.61)$ & $(-5.29)$ \\
\hline \multirow[t]{2}{*}{$\mathrm{R} \& \mathrm{D}$} & $-0.067^{\star * *}$ & $-0.060^{\star * *}$ & $-0.072^{\star * *}$ \\
\hline & $(-9.96)$ & $(-6.43)$ & $(-7.40)$ \\
\hline \multirow[t]{2}{*}{ Hold } & $0.066^{* * *}$ & $0.052^{* * *}$ & $0.089^{* * *}$ \\
\hline & $(9.12)$ & $(5.24)$ & $(8.29)$ \\
\hline \multirow[t]{2}{*}{ Constant } & 0.056 & 0.019 & 0.118 \\
\hline & $(0.96)$ & $(0.23)$ & $(1.42)$ \\
\hline Industry & Yes & Yes & Yes \\
\hline Year & Yes & Yes & Yes \\
\hline Observations & 19581 & 9971 & 9610 \\
\hline Adjusted-R2 & 0.143 & 0.128 & 0.167 \\
\hline
\end{tabular}

Standard errors in parentheses ${ }^{* * *} \mathrm{p}<0.01,{ }^{* *} \mathrm{p}<0.05,{ }^{*} \mathrm{p}<0.1$.

increase of corporate debt and R \& D investment has a negative impact on corporate performance, because the scale of debt and $\mathrm{R} \& \mathrm{D}$ investment represent cost input, the higher the cost input, the lower the performance of enterprises. The results of grouping regression show that different capital investments will have different economic consequences, which will have different effects on corporate performance. Comparing the regression coefficients of the two groups, the equity pledge that invests capital outside the enterprise has a more significant negative effect on enterprise performance. The regression coefficient starts from -0.042 to -0.060 , which is significant at $1 \%$ level. When the capital invests in the enterprise, the negative effect of equity pledge has been alleviated to a certain extent. The regression coefficient decreases from -0.042 to -0.017 , which further tests and issues. There is a significant difference in the coefficients between the two groups, Chi value is 7.75 , and at the level of $1 \%$. Through the above analysis, this paper finds that whether the capital is invested in the enter- 
prise or out of the enterprise, equity pledge has a significant negative impact on the performance of the enterprise. However, compared with investing capital in the internal operation of the enterprise, the equity pledge outside the enterprise will bring more serious negative consequences to the performance of the enterprise, that is, Hypothesis 4 of this paper has been verified.

\subsection{Robustness Test}

In the robustness test, we change the measurement indicators of enterprise risk-taking and performance test the robustness of the regression results. Firstly, the risk-taking indicators are replaced. In this paper, Roa's volatility is replaced by Roe's volatility and Ebit's volatility, and the relationship between Roa's volatility and Ebit's equity pledge ratio is tested. As shown in Table 6, whether

Table 6. Replacement of risk-taking measuring indicators.

\begin{tabular}{|c|c|c|c|c|c|c|}
\hline & \multicolumn{3}{|c|}{ Rt-roe } & \multicolumn{3}{|c|}{ Rt-ebit } \\
\hline & $\begin{array}{c}\text { Full } \\
\text { sample }\end{array}$ & $\begin{array}{c}\text { Inner } \\
\text { investment }\end{array}$ & $\begin{array}{c}\text { Outside } \\
\text { investment }\end{array}$ & $\begin{array}{c}\text { Full } \\
\text { sample }\end{array}$ & $\begin{array}{c}\text { Inner } \\
\text { investment }\end{array}$ & $\begin{array}{c}\text { Outside } \\
\text { investment }\end{array}$ \\
\hline \multirow{4}{*}{ Pledge } & $0.013^{\star *}$ & $0.030^{\star * *}$ & 0.001 & $0.044^{* * *}$ & $0.073^{* * *}$ & $0.019^{* *}$ \\
\hline & $(2.09)$ & (3.39) & $(0.08)$ & $(6.83)$ & $(7.80)$ & $(2.14)$ \\
\hline & \multicolumn{4}{|c|}{ Chi $=3.96^{\star *}$} & \multicolumn{2}{|c|}{ Chi $=11.79^{* * *}$} \\
\hline & \multicolumn{4}{|c|}{$P=0.046$} & \multicolumn{2}{|c|}{$P=0.000$} \\
\hline \multirow[t]{2}{*}{ Size } & $-0.327^{\star * *}$ & $-0.394^{* * *}$ & $-0.273^{* * *}$ & $-0.227^{\star * *}$ & $-0.264^{\star * *}$ & $-0.203^{\star * *}$ \\
\hline & $(-40.71)$ & $(-34.63)$ & $(-24.03)$ & $(-27.49)$ & $(-21.79)$ & $(-17.84)$ \\
\hline \multirow[t]{2}{*}{ Lev } & $0.365^{\star * *}$ & $0.434^{* * *}$ & $0.313^{* * *}$ & -0.009 & $0.033^{* * *}$ & $-0.037^{* * *}$ \\
\hline & $(48.10)$ & $(38.63)$ & $(30.27)$ & $(-1.18)$ & $(2.80)$ & $(-3.54)$ \\
\hline \multirow[t]{2}{*}{ Growth } & $0.035^{\star * \star}$ & $0.028^{\star * *}$ & $0.038^{\star * *}$ & $0.070^{* * *}$ & $0.044^{\star * *}$ & $0.089^{* * *}$ \\
\hline & $(7.28)$ & $(3.97)$ & $(5.61)$ & $(13.91)$ & $(5.86)$ & $(13.31)$ \\
\hline \multirow[t]{2}{*}{ Soe } & $-0.016^{* * *}$ & $-0.036^{\star * \star}$ & 0.003 & 0.005 & 0.002 & 0.009 \\
\hline & $(-2.64)$ & $(-4.19)$ & $(0.35)$ & $(0.84)$ & $(0.26)$ & (1.09) \\
\hline \multirow[t]{2}{*}{ Age } & $0.191^{\star \star *}$ & $0.189^{* * *}$ & $0.179^{\star * *}$ & $0.224^{\star * *}$ & $0.238^{\star * *}$ & $0.198^{\star * *}$ \\
\hline & $(26.87)$ & (19.37) & $(17.28)$ & $(30.79)$ & $(22.89)$ & (19.09) \\
\hline \multirow[t]{2}{*}{$\mathrm{R} \& \mathrm{D}$} & 0.004 & -0.005 & $0.015^{\star}$ & $0.014^{\star *}$ & $0.033^{* * *}$ & 0.000 \\
\hline & $(0.74)$ & $(-0.54)$ & $(1.83)$ & $(2.34)$ & $(3.52)$ & $(0.01)$ \\
\hline \multirow[t]{2}{*}{ Hold } & $-0.036^{\star * *}$ & $-0.030^{\star * *}$ & $-0.042^{* * *}$ & $-0.042^{* * *}$ & $-0.044^{\star * *}$ & $-0.043^{\star * *}$ \\
\hline & $(-5.70)$ & $(-3.31)$ & $(-4.73)$ & $(-6.46)$ & $(-4.51)$ & $(-4.92)$ \\
\hline \multirow[t]{2}{*}{ Constant } & $0.187^{\star * *}$ & $0.217^{\star * *}$ & $0.122^{\star}$ & -0.083 & 0.035 & $-0.188^{\star *}$ \\
\hline & $(3.51)$ & $(2.79)$ & (1.66) & $(-1.52)$ & $(0.43)$ & $(-2.55)$ \\
\hline Industry & Yes & Yes & Yes & Yes & Yes & Yes \\
\hline Year & Yes & Yes & Yes & Yes & Yes & Yes \\
\hline Observations & 25168 & 11440 & 13728 & 25162 & 11438 & 13724 \\
\hline Adjusted-R2 & 0.152 & 0.213 & 0.116 & 0.10 & 0.13 & 0.09 \\
\hline
\end{tabular}

Standard errors in parentheses ${ }^{* * *} \mathrm{p}<0.01,{ }^{* *} \mathrm{p}<0.05,{ }^{*} \mathrm{p}<0.1$. 
measured by Roe or Ebit, the equity pledge ratio and risk-taking are significantly positively correlated, and significantly at the level of $1 \%$ from the whole sample regression. After differentiating the capital use of equity pledge, it is also found that when capital is invested outside the enterprise, the positive impact of equity pledge on risk-taking is more significant. In the two groups, the regression coefficients are 0.03 and 0.073 , which are significant at the level of $1 \%$. In contrast, when capital is invested in the enterprise, the impact of equity pledge on risk-taking is significantly weakened, and the coefficients are reduced to 0.001 and 0.019 , respectively. The significance of equity pledge is also lower than before. One group is significantly reduced to $5 \%$, while the other is not. The test of the difference of regression coefficients also shows that there are significant differences between the two groups with different investment directions. The robustness test shows that the main regression results remain stable after the replacement of indicators to measure the risk-taking, indicating that the equity pledge has a significant positive impact on the risk-taking of enterprises, and this positive impact is regulated by the use of pledge. When capital is invested outside the enterprise, the enterprise may undertake excessive risks; otherwise the impact on the enterprise risk-taking will be relatively weak.

\section{Research Conclusion}

Based on the principal-agent theory, the theory of return on control rights and the portfolio theory, this paper combs the impact of the pledge of large shareholders' equity on corporate risk-taking and corporate performance. The study finds that with the increase of the pledge rate, the large shareholders will make more high-risk investments, thus improving the overall risk-taking level of the company. However, the improvement of risk-taking level is accompanied by the decline of enterprise performance, especially when the capital obtained by equity pledge is invested outside the enterprise. The innovation of this paper is to examine the impact of large shareholders' equity pledge behavior on corporate risk-taking from the perspective of dynamic adjustment of the portfolio of large shareholders. It reveals the inherent mechanism of the characteristics of major shareholders affecting corporate risk-taking, thus expanding the research perspective of the characteristics of major shareholders affecting corporate risk-taking.

\section{Conflicts of Interest}

The author declares no conflicts of interest regarding the publication of this paper.

\section{References}

[1] Boubakri, N., Cosset, J.C. and Saffar, W. (2013) The Role of State and Foreign Owners in Corporate Risk-Taking: Evidence from Privatization. Journal of Financial Economics, 108, 641-658. https://doi.org/10.1016/j.jfineco.2012.12.007

[2] Faccio, M., Marchica, M.T. and Mura, R. (2011) Large Shareholder Diversification and Corporate Risk-Taking. Review of Financial Studies, 24, 3601-3641. 
https://doi.org/10.1093/rfs/hhr065

[3] John, K., Litov, L. and Yeung, B. (2008) Corporate Governance and Risk-Taking. The Journal of Finance, 63, 1679-1728. https://doi.org/10.1111/j.1540-6261.2008.01372.x

[4] Bauguess, S.W., Slovin, M.B. and Sushka, M.E. (2012) Large Shareholder Diversification, Corporate Risk Taking, and the Benefits of Changing to Differential Voting Rights. Journal of Banking \& Finance, 36, 1244-1253. https://doi.org/10.1016/j.jbankfin.2011.11.009

[5] Kusnadi, Y. (2015) Insider Trading Restrictions and Corporate Risk-Taking. Pacific-Basin Finance Journal, 35, 125-142. https://doi.org/10.1016/j.pacfin.2014.11.004

[6] Mishra, D.R. (2011) Multiple Large Shareholders and Corporate Risk Taking: Evidence from East Asia. Corporate Governance: An International Review, 19, 507-528. https://doi.org/10.1111/j.1467-8683.2011.00862.x

[7] Bargeron, L.L., Lehn, K.M. and Zutter, C.J. (2010) Sarbanes-Oxley and Corporate Risk-Taking. Journal of Accounting and Economics, 49, 34-52. https://doi.org/10.1016/j.jacceco.2009.05.001

[8] Acharya, V.V., Amihud, Y. and Litov, L. (2011) Creditor Rights and Corporate Risk-Taking. Journal of Financial Economics, 102, 150-166. https://doi.org/10.1016/j.jfineco.2011.04.001

[9] Hao, X. and Liang, Q. (2009) Does the Ultimate Controller's Equity Pledge Damage the Company's Value? Accounting Research, 7, 57-63.

[10] Wang, B., Cai, A. and Feng, Y. (2013) Large Shareholders' Equity Pledge, Risk of Transfer of Control Rights and Company Performance. Systems Engineering Theory and Practice, 33, 1762-1773.

[11] Wu, J. and Tan, Y. (2013) Does Equity Pledge Have Governance Effect?-Empirical Evidence from Chinese Listed Companies. Accounting Research, No. 2, 45-53.

[12] Li, J. and Zheng, G. (2015) Controlling Shareholders' Equity Pledge Financing and Interest Embezzlement Motivated by Market value Management. Accounting Research, 5, 42-48.

[13] Amihud, Y. and Lev, B. (1990) Risk Reduction as a Managerial Motive for Conglomerate Mergers. Bell Journal of Economics, 12, 605-617. https://doi.org/10.2307/3003575

[14] Yeh, Y.H., Ko, C.E. and Su, Y.H. (2003) Ultimate Control and Expropriation of Minority Shareholders: New Evidence from Taiwan. Academic Economic Papers.

[15] Dong, Z., Wang, C. and Xie, F. (2010) Do Executive Stock Options Induce Excessive Risk Taking? Journal of Banking \& Finance, 34, 2518-2529. https://doi.org/10.1016/j.jbankfin.2010.04.010

[16] Yu, M., Li, W. and Pan, H. (2013) Managers' Overconfidence and Enterprise Risk-Taking. Financial Research, No. 1, 149-163. 